\title{
PREDATION BY NYMPHS OF PICROMERUS BIDENS (HETEROPTERA PENTATOMIDAE ASOPINAE) ON CATERPILLARS OF EUPHYDRYAS AURINIA PROVINCIALIS (LEPIDOPTERA NYMPHALIDAE) IN ITALY
}

\author{
a Department of Biology, University of Rome Tor Vergata, Via della Ricerca Scientifica 1, I-00133, Rome (Italy). \\ ${ }^{b}$ Natural History Museum of the University of Florence, Zoological Section "La Specola", Via Romana 17, I-50125 \\ Florence, Italy. \\ c Institute of Agroenvironmental and Forest Biology, CNR-National Research Council of Italy, via Salaria km 29,300, \\ I-00015 Monterotondo (Rome), Italy. \\ d Via Cherilo di Samo 40 - 00124 (Rome), Italy.

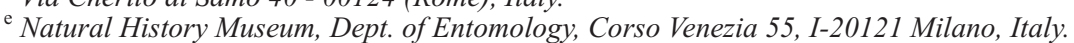 \\ Corresponding Author: Manuela Pinzari; manuela.pinzari@uniroma2.it
}

Pinzari M., Cianferoni F., Fabiani A., Dioli P. - Predation by nymphs of Picromerus bidens (Heteroptera Pentatomidae Asopinae) on caterpillars of Euphydryas aurinia provincialis (Lepidoptera Nymphalidae) in Italy.

Euphydryas aurinia (Rottemburg 1775) is one of the most seriously threatened European butterflies, as it suffered a severe decline in most countries and it is today listed in the European Community Habitats and Species Directive (92/43/EEC). Although its ecology and biology have been increasingly studied during the $20^{\text {th }}$ Century, the factors affecting its mortality have not been described in detail, and the role of natural enemies on its population dynamics is largely unknown. In this paper, we present new data on predation events of P. bidens (Linnaeus, 1758) on caterpillars of Euphydryas aurinia spp. provincialis (Boisduval, 1828) in Central Italy, and discuss the stages during which predation could have a stronger impact. Our results show that II to IV instar nymphs of $P$. bidens attack the pre-diapause $3^{\text {rd }}$ instar caterpillars when they live in a communal silken nest, while adults were found on butterfly larval webs, but never preying on caterpillars. The bugs visited a larval group more than once a day and at different times, and showed preference for cooler habitats (i.e., they were not observed on webs of warmer habitats). All together, our observations point out to the potential significant impact that gregarious nymphal instars can have on the population dynamics of E. aurinia in cooler habitats, where predator and prey coexist.

KEY WoRDS: Euphydryas aurinia provincialis, larvae, predator, Picromerus bidens.

\section{INTRODUCTION}

The ecology and biology of Euphydryas aurinia aurinia (Rottemburg, 1775) has been intensively studied in Europe (Porter, 1981; WARren, 1993; 1994; 1996; WARren et al., 1994; Klemetti \& WAhlberG, 1997; WahlberG, 2001; Hula et al., 2004; SAARINEN et al., 2005; MAZEL, 2006; Svitra \& Sielezniew, 2010; Porter \& Ellis, 2011; CASACCI et al., 2014) especially owing to its severe decline in most European countries during the 20th century (VAN SWAAY et al., 2010). However, the natural history of its enemies and their role in its population dynamics are scarcely unknown (VAN NAUHUYS \& HANSKI, 2004).

Caterpillars of E. aurinia sp. provincialis show six larval stages; during the first four, they are gregarious and live in a communal silken web (PINZARI et al., 2010, 2016, 2017) on a variety of host plants, likely playing an important role in this complex multitrophic community. In Europe, arthropods and small mammals have been reported as parasitoids or predators of E. aurinia (VAN NAUHUYS \& HANSKI, 2004). Among insect parasitoids, the impact of braconid wasps on E. a. aurinia populations has been studied in detail since the '80s (PORTER, 1981; KANKARE et al., 2005; SHAW et al., 2009), while a more recently study showed the relationship between tachinids and E. $a$. provincialis, as their host (PINZARI et al., 2017). On the contrary, scarce information is available on predation by heteropterans. In a review by VAN NAUHUYS \& HANSKI (2004) only an old report by WILKINSON (1907) is mentioned, on unidentified heteropterans predating E. a. aurinia caterpillars. In addition, two recent notes described predation on pre-hibernation caterpillars of E. a. aurinia and E. a. provincialis by true bugs Picromerus bidens (Linnaeus, 1758) Deraeocoris schach (Fabricius, 1781) respectively (KonvicKa et al., 2005; PInZARI, 2016b). In these notes, while $D$. schach seems to be an occasional predator of prehibernation caterpillars, $P$. bidens looks like a regular and efficient predator, as it was seen at adult stage attacking both butterflies and caterpillars at their fourth larval-instar stage.

Pre-hibernation caterpillars of E. a. provincialis feed gregariously and move from plant to plant (PINZARI et al., 2016), representing an important food source for P. bidens, especially when they are also in a gregarious phase. In fact, gregarious behaviour is typical of their I-II instar nymphs (LARIVIÈRE \& LAROChelle, 1989; De ClercQ, 2000) and, according to KONVICKA et al. (2005), this species could represent a substantial mortality factor in populations of butterflies.

Within this framework, in the context of an ongoing survey of the Lepidoptera fauna in central Italy (PINZARI et al., 2010; PinZari \& SBORdoni, 2013; PinZARI, 2016a; PINZARI et al., 2018a, 2018b, 2019a, PINZARI \& PINZARI, 2019a, 2019b), in 2010 we started a study on several aspects of the biology of E. aurinia sp. provincialis in 
Central Italy; we described its larval host plants preference (PINZARI et al., 2016), adult population dynamics (MANUELA PINZARI, unpublished data), mating behaviour (PINZARI et al., 2019), and, finally, we identified its main predators (PINZARI, 2016; PINZARI, 2019) and parasitoids (PINZARI et al., 2017). Here, we report our observations on bug nymphs of $P$. bidens predating the caterpillars of $E$. a. provincialis.

\section{MATERIALS AND METHODS}

\section{STUDY SPECIES}

Euphydryas aurinia provincialis (Lepidoptera: Nymphalidae) are widespread over the Central Apennines and, in particular, on Monti Reatini (data from Osservatorio per la Biodiversità del Lazio). In the study area (see below), they occupy habitat patches in montane grassland and slopes, within a mosaic of different habitats including wooded and rocky areas, hedgerows, fields and less steep areas which are occasionally ploughed and cultivated.

They have one generation per year: they lay their eggs in large clumps under plant leaves in May-June, and develop into six larval instars. The first three instars are gregarious: they spin a substantial nest between the leaves of the food plants and live together from May to August within the communal silken web; the IV instar-larvae enter diapause in August-September and overwinter in a larval web (hibernaculum) close to the ground. By February, caterpillars are again active, they complete their life-cycle and pupate by the end of April. Adults start to emerge in May (PINZARI et al., 2016).

Picromerus bidens (Hemiptera: Heteroptera: Pentatomidae, Asopinae) is distributed in continental Italy and in Sicily (FARACI et al., 1995). It is associated with a wide range of habitats, mainly on shrubs and forests of open forest edges, meadows and gardens, preferring fresh, shaded and humid areas (LARIVIËRE \& LAROCHELlE, 1989). The proximity of fresh vegetation is essential to the successful development of nymphs and adults (MAYNÈ \& BRENY, 1948) and for reproductive activity (MAHDIAN et al., 2008). Females deposit egg batches (typically 35 to 45 eggs), as many as five and varying in size (SCHUMAKER, 1911; MAYNÉ \& BRENY, 1948b; JAVAHERY, 1986 LARIVIÈRE \& LAROCHELLE, 1989), and the nymphs hatch in spring (MAYNÉ \& BRENY, 1948a; 1948b). There are five nymphal instars which, depending on ecological conditions, take from 25 to 60 days to complete development (STRAWINSKI, 1927; Southwood \& Leston, 1959; JaVAhery, 1986; DE ClercQ, 2000; Musolin \& Saulich, 2000; Saulich \& Musolin, 2014). During the I instar, the nymphs live close together in aggregations that vary in size in relationship to the number of eggs for individual batches. The II instar nymphs also tend to be gregarious, living in groups of 3-56 individuals, although they start to disperse intermittently to find prey. Activity and mobility increases from the III to the V nymphal instar (JAVAHERY, 1986).

Concerning feeding behaviour, the I instar-nymphs do not feed but only take up water (DE CLERCQ, 2000) or suck liquids from a wide diversity of plants (MAYNÉ \& BRENY, 1948b; Southwood \& Leston, 1959). Animal food is required from the II or III nymphal instars (MAYNÉ \& BRENY, 1948b). Picromerus bidens is a highly polyphagous bug that preys on larvae, pupae and adults of more than 250 species from several insect orders (LARIVIÈRE \& LAROCHELLE, 1989). It is often found on plants that are attacked by leaf-eating larvae, particularly of Lepidoptera and Coleoptera (StrawinsKy, 1927; MAYNÉ \& BRENy, 1948a, 1948b). It is a little vagile and disperses mainly by walking (MAYNÉ \& BRENY, 1948b; JAVAHERY, 1986; LARIVIÈRE \& LAROCHELLE, 1989).

\section{STUDY AREA AND LARVAL WEBS}

Our observations were carried out in 2015-2016 in an area (2 ha) ) near the "crossroads Santa Maria del Monte Fonte Brignola" (1300 m). Here, we monitored 115 larval webs of E. a. provincialis (62 in 2015 and 53 in 2016).

To daily (and more easily) observe the interaction between predators and prey, we also collected an egg batch of E. a. provincialis and established it on a host plant of Scabiosa columbaria L. (Dipsacaceae) in a clearing between trees and shrubs (Fraxinus ornus L., Fagus sylvestris Gaertn., Quercus sp., Salix caprea L., Malus sp., Acer sp., Juniperus sp., Cytisus sp., Prunus sp., Lonicera caprifolium L., Clematis vitalba L., Rubus sp., Abies alba Mill.). The area was close to our private laboratory in Colle Marcone (1121 m a.s.1.) (PINZARI et al., 2010). In this "artificial" larval web, eggs hatched successfully and larvae developed naturally. We visited this larval web during day light, as (or even more) often than the natural larval webs (i.e., every 23 hours per day), and also at night time, to ascertain possible nocturnal activities of the predators.

Over the two years, a total of 50 days were spent monitoring all egg batches and larval webs of E. a. provincialis focusing on: (i) the eggs (from May to the end of June), (ii) the pre-diapause gregarious phase (I-III instar on larval webs, from May to September), (iii) the diapause phase (IV instar in larval webs, from September to mid-February), and (iv) the post-diapause gregarious phase (IV instar, from mid-February to mid-March). We counted and collected heteropterans on butterfly larval webs. Sampling was carried out every 7-15 days throughout the year, except during winter (November to February), in all localities, visiting the larval webs along the same transect path. The path for monitoring the "natural" webs was marked by numbered flags, located at each of the host plants.

For each bug observed, we recorded the date and time of the observation, the exposure of the predator to sunlight (shade or sun), the position of the predator (plant or larval web), the behaviour of the predator (predation or not), and established the prey attacked by the predator. To identify the species of predators, some individuals were collected as vouchers and preserved dried (private collection, Pinzari Rome, Italy), while others were only photographed.

\section{RESULTS}

\section{OBSERVATIONS ON PICROMERUS BIDENS}

During our observations on the 115 larval webs, we did not record the presence of $P$. bidens, which was instead observed on the "artificial" web in Colle Marcone, while it was preying on caterpillars. In particular, we sampled six nymphs and three adults in 2015, and observed 13 individuals without collecting them. Only a single nymph was collected in 2016 as voucher.

Twice in June 2015 and once in July 2016 (Fig. I), we observed II to IV instar nymphs of $P$. bidens on a larval web of $E$. a. provincialis, while preying on the prediapause III instar caterpillars (Fig. II, 1-4). No V instar nymphs were observed. Nymphs and adults of $P$. bidens were not seen in August; on the contrary, adults were found on larval webs or in their vicinity, on three occasions. In particular, we found: (i) a female at a distance of ca. $1 \mathrm{~m}$ from the larval web, on $26^{\text {th }}$ September 
2015; (ii) a male attacking a larva of an unidentified sawfly (Hymenoptera, Symphyta) (Fig. II, 5) near a larval web, on 29 ${ }^{\text {th }}$ September 2015; (iii) an adult (sex not identified) on the larval web, but not attacking the caterpillars, on $4^{\text {th }}$ October 2015 (Fig. II, 5-6).

As far as sunlight exposure is concerned, the larval web in Colle Marcone was located within woodland and shrubs. It was in shade until $11 \mathrm{AM}$; during the following hours it was in sunlight until 3 PM and then in moderate-shade until sunset. We found P. bidens on host larval webs or nearby throughout the day (Fig. III). Our data show that different stages of this bug occurred at the larval webs at different times of a day. In particular, the II instar nymph visited the larval webs of $E$. a. provincialis mainly during the morning, while the III instar nymph stayed on the nest longer into the

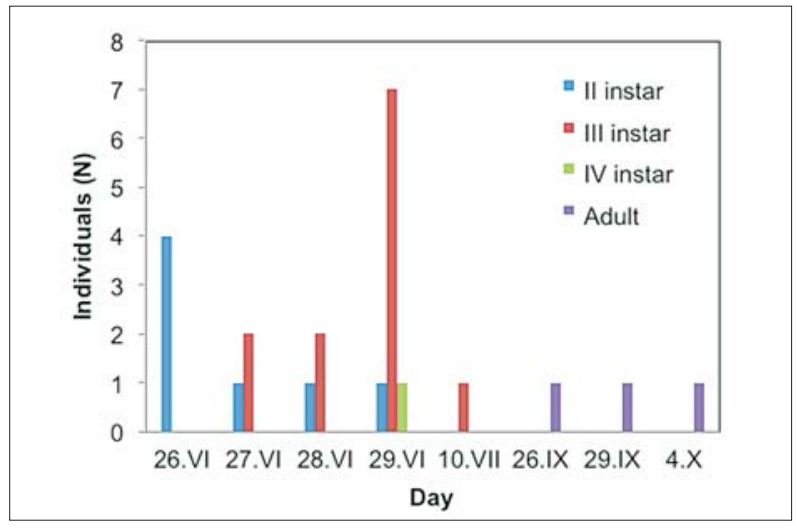

Fig. I - Occurrence of nymphs and adults of Picromerus bidens on the larval web of E. a. provincialis (Loc. Colle Marcone, $1121 \mathrm{~m}$ a.s.1.) in 2015-2016. Some records could involve individuals that have been observed repeatedly.

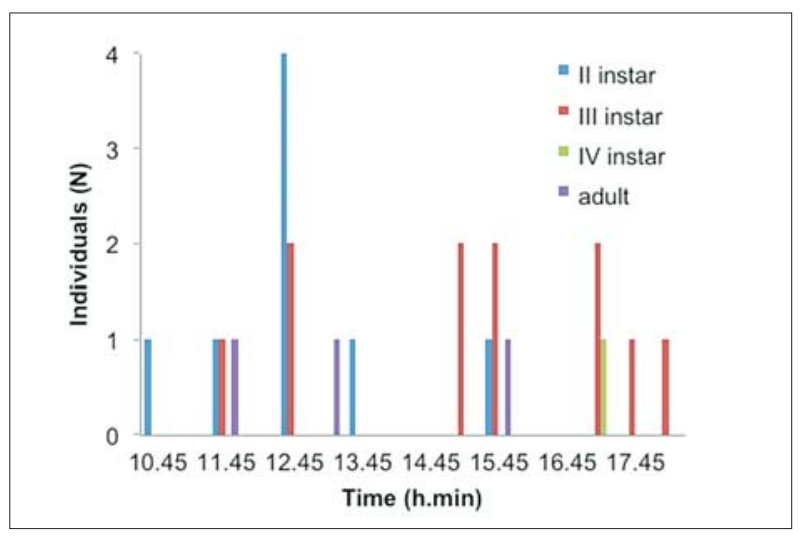

Fig. III - Picromerus bidens: clock time of the observations of nymphs and adults in 2015-2016 at Loc. Colle Marcone.

afternoon (Fig. III). During nocturnal observations, we did not find any predators either on larval web or in their vicinity.

NOTES ON PREDATION BEHAVIOUR

We observed seven nymphs of $P$. bidens feeding on the caterpillars of E. a. provincialis.

During predation, the nymphs remained at the external edge of larval web and explored only the web surface of the older webbing of the nest. When they found a potential prey (i.e., the nearest caterpillar), they attacked the larva by piercing it with its stylet: they raised it with their beak, and moved away; then, they hid between leaves at a distance of ca. 20-30 cm from the nest and consumed the prey (Fig. II, 1-3).

On the $29^{\text {th }}$ of June 2015 , a II instar nymph approached the larval mass only when the nest was in sunlight and larvae were still inside the silk web (Fig. II, 1).

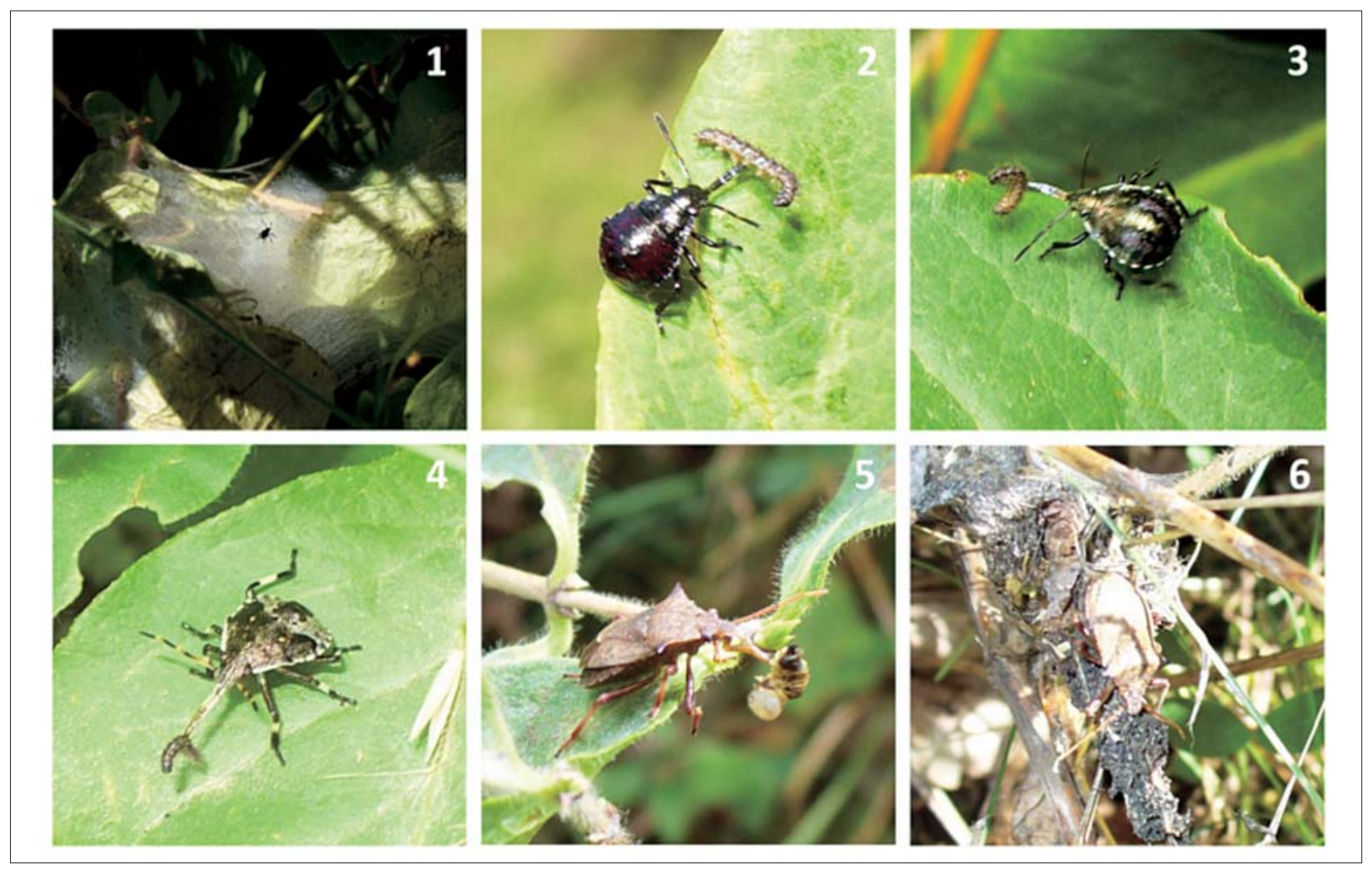

Fig. II - Predation by P. bidens on gregarious larvae of E. a. provincialis in a larval web on L. caprifolium: 1) a II instar nymph (29.VI.2015); 2) a II instar nymph (27.VI.2015); 3) a III instar nymph (29.VI.2015); 4) a IV instar nymph (29.VI.2015); 5) an adult while preying on a larva of unidentified sawfly (Symphyta) close to a larval web (27.IX.2015); 6) an adult on a larval web (4.X.2015). 
We observed adults of $P$. bidens on a larval web of $E$. $a$. provincialis but we never recorded their predation events on caterpillars. On the larval web surface, we photographed only one adult preying, but it fed on a larva of unidentified sawfly (Hymenoptera, Symphyta) (Fig. II, 5).

\section{DISCUSSION}

Picromerus bidens is a generalist predator of a wide range of insects, including moths and butterflies (LARIVIÈRE \& LAROCHELLE, 1989). For such a generalist, the pre-hibernation caterpillars of $E$. a. provincialis might represent an important food source for adult bugs and, even more, for their gregarious nymphs.

Gregarious behaviour is typical of the I-II instar nymphs of $P$. bidens (LARIVIÈRE \& LAROCHELLE, 1989; DE CLERCQ, 2000), whenever the nymphs discover a large source of food (i.e., a butterfly larval web) they remain around it, even if they are no longer gregarious (III and IV nymphal instars). As they grow into the $\mathrm{V}$ instar stage, they may need larger preys and, therefore, abandon the butterfly larval webs (JAVAHERY, 1986).

During our observations, nymphs of $P$. bidens attacked caterpillars of $E$. a. provincialis quite efficiently and visited a single larval group repeatedly through time (from II to IV nymphal instars, Fig. III), acting as a potential and substantial mortality factor for our endangered study species.

Similar prey behaviour was, in fact, described for the V nymphal instar of $P$. bidens on the endangered $E$. maturna in Germany (DoLEK et al., 2007), and authors raised their worries on its potential impact on this species.

The absence of I instar nymphs $P$. bidens on larval webs of $E$. a. provincialis collates with the fact that they are not predators at this age (SouTHWOOD \& LESTON, 1959). Adults can instead attend larval webs and then, we surmise, feed on butterfly larvae, as already observed for E. a. aurinia by Konvicka et al. (2005) in western Bohemia, Czech Republic. Unfortunately, we never recorded predation events on caterpillars by adult bugs.

To evaluate the predatory impact on E. a. provincialis, two major factors need to be taken into account: the habitat of the interacting organisms and the population size of predators and prey.

In the study area, E. a. provincialis can be found in both "cool and humid" and "warm and arid" habitat patches in montane grassland. On the contrary, according to JAVAHERY (1986), P. bidens in our study area prefers "cool and humid" patches and does not tolerate high temperatures. During our observations, when the larval web was in sunlight, both adult and nymph bugs used to hide in the vegetation in shaded areas, similarly to its prey; the caterpillars of $E$. $a$. provincialis also remained in the shaded parts of their host plant and retreated into the larval webs, when the temperature was getting higher. We therefore recorded the coexistence of $P$. bidens and $E$. a. provincialis only in Colle Marcone, which is characterized by cool and damp microclimate, while we never observed them together in warmer areas of our study area (such as "crossroads Santa Maria del Monte - Fonte Brignola"). As we did not observed P. bidens on any of the 115 webs in the field, we can state with some certainty that $P$. bidens was (and it is) absent in those warmer areas; nevertheless, we were not able to quantify the exact population size of bugs in the cool site where it occurred together with our butterfly. For this reason, we believe that a dedicated study carried out in the cooler habitats of $E$. a. provincialis would be needed, to ascertain the occurrence of $P$. bidens, to estimate the abundance of bugs and butterflies and, therefore, the impact of this predator on butterfly mortality.

It is also important to underline that consumption and developmental duration of the predatory stages of $P$. bidens is affected by temperature (MAHDIAN et al., 2006a, 2006b, 2008), which means that the species could adopt different developmental and feeding strategies in different habitats and the predatory effect on the butterfly population size could vary seasonally.

The predatory effect on larvae of $E$. $a$. provincialis by $P$. bidens was difficult to gauge, as we could not use permanent marking on the nymphs (because of their moulting), and individuals on larval webs could have been observed and counted repeatedly. However, we could estimate the minimum and maximum numbers of nymphs, considering that we captured six individual nymphs and observed 13 predator events (see Results). If the individuals observed were different, the total number of nymphs on our plant would be 19 (i.e., six captured plus 13 observed); if instead we observed only one individual, our total number would be 7 (i.e., six captured plus 1 observed). This range of 7-13 nymphs is consistent with that found by JAVAHERY (1986), who observed aggregations of 3-56 individuals.

The number of caterpillars in larval webs greatly varies depending on the host plant: from the few dozen larvae on Scabiosa columbaria to hundreds on Gentiana cruciata L. (Gentianaceae) (PINZARI et al., 2017). If we consider that nymphs return several times on the same plant to eat, and gravitate around the larval web at the III-IV instar stages, it is clear that they can represent an important threat for the caterpillar survival. Moreover, due to the gregarious behaviour of predators and preys, $P$. bidens nymphs of only a single egg batch could easily annihilate an entire larval web of caterpillars, with serious consequences on the survival of butterflies in that target area.

\section{CONCLUDING REMARKS}

In Euphydryas butterflies, larval mortality caused by generalist predators as $P$. bidens does occur and is occasionally severe (EHRLICH \& HANSKI, 2004). Picromerus bidens could represent an important regulatory factor influencing the population of $E$. a. provincialis, as suggested for the rare butterfly E. maturna (VRABEC \& JINDRA, 1998; VOINOT \& ESSAYAN, 2015). The gregarious predatory behaviour displayed by early nymphal stages of $P$. bidens could strongly affect butterfly population size, especially in the case of small larval webs. However, the predatory impact of $P$. bidens on $E$. a. provincialis should be further evaluated, within a larger study including the effect of also other predators - among which, the true bug Deraeocoris schach (PINZARI, 2016), the theridiid spider Phylloneta sisyphia (Clerck, 1757) (PINZARI, 2019), the specialized parasitoids, tachinid fly Erycia furibunda (PINZARI et al., 2016) and likely many other unidentified species.

\section{ACKNOWLEDGMENTS}

We would like to thank Mario Pinzari (Rome, Italy) for his technical support during the field work and Prof. Valerio Sbordoni (Department of Biology, Tor Vergata University of Rome, Italy) for his general support during the study; special thanks go to Prof. Roger L.H. Dennis (Centre for 
Ecology, Environment and Conservation, Oxford Brookes University), for his comments and suggestions on the final version of the manuscript.

The present study is a part of the project of the Osservatorio per la Biodiversità del Lazio $(\mathrm{OBL})$, coordinated by Prof. Valerio Sbordoni, on behalf of "Assessorato Ambiente" e "Cooperazione tra i Popoli della Regione Lazio" aiming at providing guidelines to monitor those species protected under the Habitat Directive 92/43/CEE (Art. 17, par. 1). Because E. aurinia is a protected species under the Natura 2000 network, capture, manipulation and sample collecting of this butterfly was performed under permission of The Ministry of Environment (Prot.0032150 23/04/2013 - PNM-II).

\section{REFERENCES}

Casacci L.P., Cerrato C., Barbero F., Bosso L., Ghidotti S., Paveto M., Pesce M., Plazio E., Panizza G., Balletto E., Viterbi R., Bonelli S., 2014 - Dispersal and connectivity effects at different altitudes in the Euphydryas aurinia complex. - J. Insect Conserv., 19(2): 265-277.

Dolek M., Freese-Hager A., Cizek O., Gros P., 2007 Mortality of early instars in the highly endangered butterfly Euphydryas maturna (Linnaeus, 1758) (Nymphalidae). - Nota lepid., 29(3/4): 221-224.

FARACI F., RizzotTI Vlach M., D'URSo V., 1995 - Heteroptera, Homoptera. Checklist Fauna Italiana, 41 - 42, Edagricole, $96 \mathrm{pp}$.

Hula V., Konvicka M., Pavlicko A., Zdenek F., 2004 Marsh-Fritillary (Euphydryas aurinia) in the Czech republic: monitoring, metapopulation structure, and conservation of an endangered butterfly. - Entomol. Fennica, 15: 231-241.

JAVAHERY M., 1986 - Biology and ecology of Picromerus bidens (Hemiptera: Pentatomidae) in southeastern Canada. - Entomol. News, 97(3): 87-98.

Kankare M., Stefanescu C., Van Nouhuys S., Shaw M.R., 2005 - Host specialization by Cotesia wasps (Hymenoptera: Braconidae) parasitizing species-rich Melitaeini (Lepidoptera: Nymphalidae) communities in north-eastern Spain. - Biol. J. Linn. Soc. Lond., 86: 45-65.

Klemetti T., Whalberg N., 1997 - Punakeltaverkkoperhosen (Euphydryas aurinia) ekologia ja populaatiorakenne Suomessa. - Baptria, 22: 87-93.KonvICKA M., Hula V., Fric Z., 2005 - Picromerus bidens (Heteroptera: Pentatomidae) as predator of the Checkerspot Euphydryas aurinia (Lepidoptera: Nymphalidae). Entomol. Fennica., 16: 233-236.

LARIVIÉRE M.C., LAROCHELle A., 1989 - Picromerus bidens (Heteroptera: Pentatomidae) in north America with a world review of its distribution and bionomics. - Entomol. News, 100(4): 133-146.

Leston D., 1955 - The life-cycle of Picromerus bidens (L.)(Hem., Pentatomidae) in Britain. - Entomol. Month. Mag., 91: 109.

Mahdian K., Kerckhove J., Tirry L. , De Clerce P., 2006a - Effects of diet on development and reproduction of predatory pentatomids Picromerus bidens and Podisus maculiventris. - BioControl, 51: 725-739.

Mahdian K., Vantornhout I., Tirry L., De ClercQ P., 2006b - Effects of temperature on predation by the stinkbugs Picromerus bidens and Podisus maculiventris (Heteroptera: Pentatomidae) on noctuid caterpillars. Bull. Entomol. Res., 96: 489-496.
Mahdian K., Tirry L., De ClercQ P., 2008 - Development of the predatory pentatomid Picromerus bidens (L.) at various constant temperatures. - Belg. J. Zool., 138(2): $135-139$.

MAYNÉ R., BRENy R. 1948a - Picromerus bidens L. La vie larvaire au premier age. - Parasitica, 3(4): 1-20.

MAYNÉ R., BRENY R., 1948b - Picromerus bidens L. . Morphologie. Biologie. Determination de sa valeur d'utilisation dans la lute biologique contre le doryphore de la pomme de terre. La valeur économique anticoryphorique des Asopines indigènes belges. - Parasitica, 4(4): $189-224$.

MAZEL R., 2006 - Déterminisme et stratégie de choix des plantes hôtes chez Euphydryas aurinia Rott. (Lepidoptera, Nymphalidae). - Revue de l'Association roussillonnaise d'entomologie, 15(2): 78-83.

Musolin D.L., SAULICH A.H., 2000 - Summer dormancy ensures univoltinism in the predatory bug Picromerus bidens. - Entomol. Exp. Appl., 95: 259-267.

PINZARI MANUELA, 2016a - Scythris clavella (Zeller, 1855) in Italy (Lepidoptera, Gelechioidea, Scythrididae). Journal of Entomological and Acarological Research, 48: 301-303.

Pinzari Manuela, 2016b - Deraeocoris schach (Heteroptera: Miridae), a new predator of Euphydryas aurinia and other heteropteran feeding habits on caterpillar web (Heteroptera: Miridae; Lepidoptera: Nymphalidae). - Fragm. Entomol., 48(1): 77-81.

Pinzari Manuela, 2019 - Phylloneta sisyphia (Clerck, 1757) (Araneae: Theridiidae), a predator of larvae of Euphydryas aurinia (Rottemburg, 1775) (Lepidoptera: Nymphalidae) and its parasitoid Erycia furibunda (Zetterstedt, 1844) (Diptera: Tachinidae). - Acta zool. bulg., 71 (2), 2019: 195-200.

Pinzari Manuela, Pinzari Mario, Zilli A., 2010 - Deep lepidopterological exploration of Mt Cagno and surroundings (Central Italy), a restricted mountain massif and hotspot for butterfly and moth diversity (Lepidoptera). - Bollettino dell'Associazione Romana di Entomologia, 65 (1-4): 3-383.

Pinzari Manuela, Sbordoni V., 2013 - Species and mate recognition in two sympatric Grayling Butterflies. Hipparchia fagi and $\mathrm{H}$. hermione genava (Lepidoptera). Ethol. Ecol. Evol., 25: 28-51.

Pinzari Manuela, Pinzari Mario, Sbordoni V., 2016 Egg laying behaviour, host plants and larval survival of Euphydryas aurinia provincialis (Lepidoptera Nymphalidae) in a Mediterranean population (Central Italy). - Bollettino della Società Entomologica Italiana, 148(3): 121-140.

Pinzari Manuela, Pinzari Mario, Sbordoni V., 2017 Notes on life-history of Erycia furibunda (Diptera Tachinidae), a parasitoid of Euphydryas aurinia provincialis (Lepidoptera Nymphalidae). - Redia, 100: 81-87. http://dx.doi.org/10.19263/REDIA-100.17.10

Pinzari Manuela, Santonico M., Pennazza G., Martinelli E., Capuano R.M., Paolesse R., Di Rao M., D’amico A., Cesaroni D., Sbordoni V., Di Natale C. $2018 \mathrm{a}$ - Chemically mediated species recognition in two sympatric Grayling butterflies: Hipparchia fagi and Hipparchia hermione (Lepidoptera: Nymphalidae, Satyrinae). - Plos One, 13: e0199997.

Pinzari Manuela, Zerunian Z., PinZari M., 2018b - Is the alien species Clepsis peritana (Lepidoptera: Tortricidae) settling in Italy? - Journal of Entomological and Acarological Research, 50(7551): 1-3.

Pinzari Manuela, PinZari Mario, Sbordoni V., 2019 - 
Make it simply: the mating behaviour of Euphydryas aurinia provincialis (Lepidoptera: Nymphalidae). - The European Zoological Journal, 86(1): 220-232.

Pinzari Manuela, Pinzari Mario, 2019a - Genus Pempeliella Caradja, 1916 and P. bayassensis Leraut, 2001 (Lepidoptera, Pyralidae) in Italy. - ZooKeys, 854: 131-144.

Pinzari Manuela, Pinzari Mario 2019b. Genus Delplanqueia Leraut, 2001 and D. inscriptella (Duponchel, 1836) (Lepidoptera: Pyralidae) in Italy. - Journal of Entomological and Acarological Research, 51:8168.

PORTER K., 1981 - The population dynamics of small colonies of the butterfly Euphydryas aurinia [D. Phil. Thesis]. Oxford (UK): University of Oxford. (England).

Porter K., Ellis S., 2011 - Securing viable metapopulations of the Marsh Fritillary butterfly, Euphydryas aurinia, (Lepidoptera: Nymphalidae) in Northern England. - J. Insect Conserv., 15: 111-119.

SAARINEN K., JANTUNEN J., VALTONEN A., 2005 - Resumed forest grazing restored a population of Euphydryas aurinia (Lepidoptera: Nymphalidae) in SE Finland. European Journal of Entomology, 102: 683-690.

Saulich A.H., Musolin D.L., 2014 - Seasonal Cycles in Stink Bugs (Heteroptera, Pentatomidae) from the Temperate Zone: Diversity and Control. - Entomol. Rev., 94(6): 785-814.

Schumaker F., 1911 - Beitrage zur Kenntnis der Biologie der Asopiden. - Z. Wiss. Insekt. Biol., 7: 40-47.

Shaw M.R., Stefanescu C., Van Nouhuys S., 2009 Parasitoids of European butterflies. In: Ecology of butterflies in Europe. Settele J., Shreeve T., Konvicka M., Van Dyck H., Eds. Cambridge University Press, Cambridge, $526 \mathrm{pp}$.

SOUTHWOOD T.R.E., LESTON D., 1959 - Land and water bugs of the British Isles. Frederick Warne, London and New York, 436 pp.

StraWInSKI K., 1927 - Picromerus bidens L. (Hemipt. Heterroptera, Pentatomidae). - Pol. Pismo Entomol., 6: 123-151.

Svitra G., SiElezniEv M., 2010 - The first observation of Euphydryas aurinia (Lepidoptera, Nymphalidae) developing on Gentiana cruciata in Lithuania. - Pol. J. Entomol., 79: 195-201.

VAN NAuHuYs S., HANSKI I., 2004 - Natural enemies of
Checkerspots. In: On the wings of checkerspots: A model system in population ecology. Ehrlich P.R., Hanski I., Eds. Oxford University Press, Oxford. 371 pp.

Van SwaAy C., Wynhoff I., Verovnik R., Wiemers M., López Munguira M., Maes D., Sasic M., Verstrael T., WARREN M., SETtEle J. 2010 - Euphydryas aurinia. The IUCN Red List of Threatened Species: e.T174182 A7024283.

VoINOT C., Essayan R., 2015 - Observations de prédations sur ponte et chenilles d'Euphydryas maturna (Linné, 1758) en Bourgogne en 2015. (Lepidoptera Nymphalidae Nymphalinae) - Alexanor, 27(3): 184-188.

VRABEC V., JINDRA Z., 1998 - The caterpillars of the rare butterfly Euphydryas maturna (Lepidoptera: Nymphalidae) as food for the predatory bug Picromerus bidens (Heteroptera: Pentatomidae). - Entomol. Probl., 29(2): 87-90.

WAHLBERG N., 2001 - The phylogenetics and biochemistry of host-plant specialization in Melitaeine butterflies (Lepidoptera:Nymphalidae). - Evolution, 55(3): 522-537.

WahlberG N., Kullberg J., Hanski I., 2001 - Natural history of some Siberian melitaeine butterfly species (Nymphalidae:Melitaeini) and their parasitoids. Entomol. Fennica, 12: 72-77.

WARREN M.S., 1993 - Observations on the use of honeysuckle (Lonicera periclymenum) as a natural food-plant of the Marsh Fritillary (Eurodryas aurinia) (Lepidoptera: Nymphalidae) in southern Britain. - Entomologist's Gazette, 44: 241-244.

WARREN M.S., 1994 - The UK status and suspected metapopulation structure of a threatened European butterfly, the marsh fritillary Eurodryas aurinia. - Biol. Cons., 67: 239-249.

WARREN M.S., 1996 - Euphydryas aurinia. In: Van Helsdingen P.J., Willemse L.P.M., Speight M.C.D. (eds.), Background information on invertebrates of the Habitats Directive and the Bern Convention. Part I - Crustacea, Coleoptera and Lepidoptera: 121-126. Council of Europe, Strasbourg, Nature and environment, No. 79.

Warren M.S., Munguira M.L., Ferrin J., 1994 - Notes on the distribution, habitats and conservation of Eurodryas aurinia (Rottemburg) (Lepidoptera: Nymphalidae) in Spain. - Entomologist's Gazette, 45: 5-12. 